\title{
New quaternary alumogermanides with the structure type $\mathrm{SmNiAl}_{4} \mathrm{Ge}_{2}$
}

\author{
Mar'yana PETROVSKA ${ }^{1}$, Nastasia KLYMENTIY ${ }^{1}$, Svitlana PUKAS $^{1}$ *, Roman GLADYSHEVSKII ${ }^{1}$ \\ ${ }^{1}$ Department of Inorganic Chemistry, Ivan Franko National University of Lviv, \\ Kyryla i Mefodiya St. 6, 79005 Lviv, Ukraine \\ * Corresponding author.Tel.: +380-32-2394506; e-mail: svitlana.pukas@lnu.edu.ua
}

Received May 1, 2018; accepted June 27, 2018; available on-line January 1, 2019

Six rare-earth nickel alumogermanides $\mathrm{RNiAl}_{4} \mathrm{Ge}_{2}(R=\mathrm{Gd}, \mathrm{Tb}, \mathrm{Dy}, \mathrm{Ho}, \mathrm{Tm}, \mathrm{Lu})$ were synthesized by arc melting and their crystal structures were studied by X-ray powder diffraction. They are isotypic to $\mathrm{SmNiAl}_{4} \mathrm{Ge}_{2}$, Pearson symbol $h R 24$, space group $R-3 m$. The structures of the $R \mathrm{NiAl}_{4} \mathrm{Ge}_{2}$ compounds can be described as formed by two types of alternating slabs. The first type of slab is built up of cubes of composition $\mathrm{Al}_{8}$, every second cube being centered by a $\mathrm{Ni}$ atom, and the second one is formed by octahedra of composition $\mathbf{G e}_{6}$, every second octahedron being centered by an $R$ atom.

\section{Rare-earth nickel alumogermanide / X-ray powder diffraction / Crystal structure}

\section{Introduction}

In the $R-\mathrm{Ni}-\mathrm{Al}-\mathrm{Ge}$ systems, where $R$ is a rare-earth metal, 29 quaternary compounds have been reported [1-3]. The structures of these alumogermanides belong to ten different structure types, among which six are defined on quaternary compounds: $\mathrm{Er}_{5} \mathrm{Ni}_{3} \mathrm{Al}_{3} \mathrm{Ge}_{4}$ (Pearson symbol oP30, space group Pmmn) [4], $\mathrm{Y}_{3} \mathrm{NiAl}_{3} \mathrm{Ge}_{2}(h P 9, P-62 m)$ [5], $\mathrm{Tb}_{2} \mathrm{NiAl}_{4} \mathrm{Ge}_{2}(t I 18$, I4/mmm) [6], $\mathrm{Ce}_{2} \mathrm{NiAl}_{5.77} \mathrm{Ge}_{2.64}$ (tI38, I4/mmm) [6], $\mathrm{SmNiAl}_{4} \mathrm{Ge}_{2}(h R 24, R-3 m)$ [7], and $\operatorname{Pr}\left(\mathrm{Ni}_{0.2} \mathrm{Al}_{0.5} \mathrm{Ge}_{0.3}\right)_{2}$ $(o S 6, C m m 2)$ [8]. The first five types are characterized by well-defined compositions and complete ordering of the atoms in the structures, whereas the last type exhibits $\mathrm{Ni} / \mathrm{Al} / \mathrm{Ge}$ atom disorder. Complete rows of isotypic alumogermanides are not known for any types. The hexagonal $\mathrm{Y}_{3} \mathrm{NiAl}_{3} \mathrm{Ge}_{2}$ type has the largest number of representatives in the $R-\mathrm{Ni}-\mathrm{Al}-\mathrm{Ge}$ systems ( 9 compounds, $R=\mathrm{Sm}, \mathrm{Gd}$, Tb, Dy, Ho, Er, Tm, Yb, $\mathrm{Lu}$ [2,9]). The tetragonal $\mathrm{Tb}_{2} \mathrm{NiAl}_{4} \mathrm{Ge}_{2}$ type has 8 representatives $(R=\mathrm{Y}, \mathrm{Sm}, \mathrm{Gd}, \mathrm{Dy}, \mathrm{Ho}, \mathrm{Er}, \mathrm{Tm}, \mathrm{Yb}$ $[3,10])$, the rhombohedral $\mathrm{SmNiAl}_{4} \mathrm{Ge}_{2}$ type has two isotypic compounds, with $\mathrm{Y}$ and $\operatorname{Er}[7,10]$, whereas the other three structure types are the only representatives of the types they define. The heavy rare-earth elements form a larger number of compounds (22) than the light rare-earth elements (7).

The aim of the present work was to search for new representatives of the structure type $\mathrm{SmNiAl}_{4} \mathrm{Ge}_{2}$ in $R-\mathrm{Ni}-\mathrm{Al}-\mathrm{Ge}$ systems. It is interesting to note that compounds adopting this structure type have also been observed in some $R-\mathrm{Au}-\mathrm{Al}-\mathrm{Ge}$ systems $(R=\mathrm{Ce}, \mathrm{Nd}$, Gd, Er) [11].

\section{Experimental}

Samples of nominal composition $R_{12.5} \mathrm{Ni}_{12.5} \mathrm{Al}_{50} \mathrm{Ge}_{25}$ $(R=\mathrm{Sc}, \mathrm{La}, \mathrm{Ce}, \mathrm{Pr}, \mathrm{Nd}, \mathrm{Eu}, \mathrm{Gd}, \mathrm{Tb}, \mathrm{Dy}, \mathrm{Ho}, \mathrm{Tm}, \mathrm{Yb}$, $\mathrm{Lu}$ were synthesized from the elements (purity for $R \geq 99.75, \quad \mathrm{Ni} \geq 99.99, \quad \mathrm{Al} \geq 99.998$, $\mathrm{Ge} \geq 99.999$ mass \%) by arc melting in a water-cooled copper crucible with a tungsten electrode under a purified argon atmosphere (using $\mathrm{Ti}$ as a getter). The ingots were annealed at $600^{\circ} \mathrm{C}$ under vacuum in quartz ampoules for 1 month and subsequently quenched in cold water. The weight loss during the preparation of the samples was less than $1 \%$ of the total mass, which was $1 \mathrm{~g}$ for each alloy.

The crystal structures of the new compounds were established by X-ray powder diffraction. Data for polycrystalline samples were collected on an automatic diffractometer STOE STADI P $\left(\mathrm{Cu} K \alpha_{1}\right.$ radiation, $\lambda=1.5406 \AA$, in the angular range $6 \leq 2 \theta \leq 110.625^{\circ}$ with step $0.015^{\circ}$ and scan time $250 \mathrm{~s})$. The structural parameters were refined by the Rietveld method [12], using the program DBWS [13]. The elemental compositions of the phases in the sample with Ho were determined by energy-dispersive $\mathrm{X}$-ray spectroscopy on a scanning electron microscope REMMA-102-02. The structure drawings were made with the program ATOMS [14].

\section{Results and discussion}

The X-ray phase analysis of the alloys annealed at $600^{\circ} \mathrm{C}$ showed that the samples with $\mathrm{Gd}, \mathrm{Tb}, \mathrm{Dy}, \mathrm{Tm}$, 
and $\mathrm{Lu}$ were single-phase and contained the compound $R \mathrm{NiAl}_{4} \mathrm{Ge}_{2}$, which is new for these rareearths. The crystal structures effectively belong to the $\mathrm{SmNiAl}_{4} \mathrm{Ge}_{2}$ type. In addition to the new compound $\mathrm{HoNiAl}_{4} \mathrm{Ge}_{2}$, the sample with Ho contained a small quantity $(2$ mass $\%)$ of a secondary phase, $\mathrm{Ni}_{2} \mathrm{Al}_{3}$ (Fig. 1). The compositions of both phases were confirmed by EDX analysis. The samples with Sc, La, $\mathrm{Ce}, \mathrm{Pr}, \mathrm{Nd}, \mathrm{Eu}$, and $\mathrm{Yb}$ were multi-phase alloys and did not contain the phase $R \mathrm{NiAl}_{4} \mathrm{Ge}_{2}$. Based on the $\mathrm{X}$-ray diffraction data, the structural parameters of the compounds $R \mathrm{NiAl}_{4} \mathrm{Ge}_{2}(R=\mathrm{Gd}, \mathrm{Tb}, \mathrm{Dy}, \mathrm{Ho}, \mathrm{Tm}, \mathrm{Lu})$ were determined.

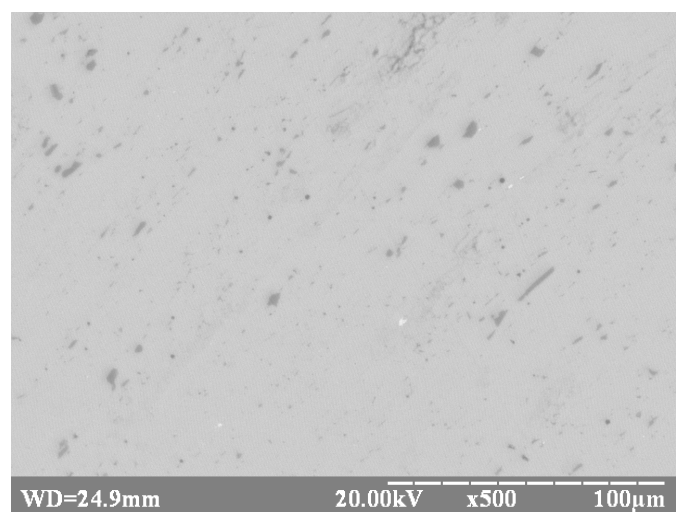

Fig. 1 Electron microscope photograph of the alloy $\mathrm{Ho}_{12.5} \mathrm{Ni}_{12.5} \mathrm{Al}_{50} \mathrm{Ge}_{25}\left(\mathrm{HoNiAl}_{4} \mathrm{Ge}_{2}-\right.$ light grey, $\mathrm{Ni}_{2} \mathrm{Al}_{3}$ - dark grey).

The cell parameters of all known quaternary alumogermanides $\quad R \mathrm{NiAl}_{4} \mathrm{Ge}_{2}$ isotypic with $\mathrm{SmNiAl}_{4} \mathrm{Ge}_{2}$ are listed in Table 1. The cell parameters refined for the new compounds $R \mathrm{NiAl}_{4} \mathrm{Ge}_{2}(R=\mathrm{Gd}$, $\mathrm{Tb}, \mathrm{Dy}, \mathrm{Ho}, \mathrm{Tm}, \mathrm{Lu})$ are in good agreement with those reported in the literature for $\mathrm{YNiAl}_{4} \mathrm{Ge}_{2}$ [7], $\mathrm{SmNiAl}_{4} \mathrm{Ge}_{2}$ [7], and $\mathrm{ErNiAl}_{4} \mathrm{Ge}_{2}$ [10]. As expected, the cell parameters decrease with decreasing radius of the rare-earth metal [15] from Sm to Lu.

Table 1 Cell parameters of $\mathrm{RNiAl}_{4} \mathrm{Ge}_{2}$ compounds with $\mathrm{SmNiAl}_{4} \mathrm{Ge}_{2}$-type structure.

\begin{tabular}{l|l|l|l}
\hline \multicolumn{1}{c|}{ Compound } & \multicolumn{1}{c|}{$a, \AA$} & \multicolumn{1}{c}{$c, \AA$} & \multicolumn{1}{c}{$V, \AA^{3}$} \\
\hline $\mathrm{YNiAl}_{4} \mathrm{Ge}_{2}{ }^{\mathrm{a}}$ & 4.0959 & 30.958 & 449.8 \\
$\mathrm{SmNiAl}_{4} \mathrm{Ge}_{2}{ }^{\mathrm{a}}$ & 4.1121 & 31.109 & 455.6 \\
$\mathrm{GdNiAl}_{4} \mathrm{Ge}_{2}$ & $4.09456(9)$ & $30.9672(9)$ & $449.623(12)$ \\
$\mathrm{TbNiAl}_{4} \mathrm{Ge}_{2}$ & $4.08419(7)$ & $30.8699(7)$ & $445.943(14)$ \\
$\mathrm{DyNiAl}_{4} \mathrm{Ge}_{2}$ & $4.08274(7)$ & $30.7857(7)$ & $444.410(15)$ \\
$\mathrm{HoNiAl}_{4} \mathrm{Ge}_{2}$ & $4.07878(3)$ & $30.7444(3)$ & $442.952(6)$ \\
$\mathrm{ErNiAl}_{4} \mathrm{Ge}_{2}{ }^{\mathrm{b}}$ & 4.0716 & 30.7027 & 440.8 \\
$\mathrm{TmNiAl}_{4} \mathrm{Ge}_{2}$ & $4.06883(3)$ & $30.6533(3)$ & $439.487(7)$ \\
$\mathrm{LuNiAl} \mathrm{Ge}_{2}$ & $4.06074(3)$ & $30.5992(3)$ & $436.970(6)$ \\
\hline${ }^{\mathrm{a}}$ from $[7],{ }^{\mathrm{b}}$ from [10]
\end{tabular}

Details of the structural refinements (pseudo-Voigt function for profile), refinable atomic coordinates and displacement parameters of the six new compounds $R \mathrm{NiAl}_{4} \mathrm{Ge}_{2}$ are presented in Table 2. A comparison of the experimental and calculated diffraction diagrams for $\mathrm{HoNiAl}_{4} \mathrm{Ge}_{2}$ is shown in Fig. 2. Relevant interatomic distances for the six new compounds and the corresponding coordination polyhedra are presented in Table 3.

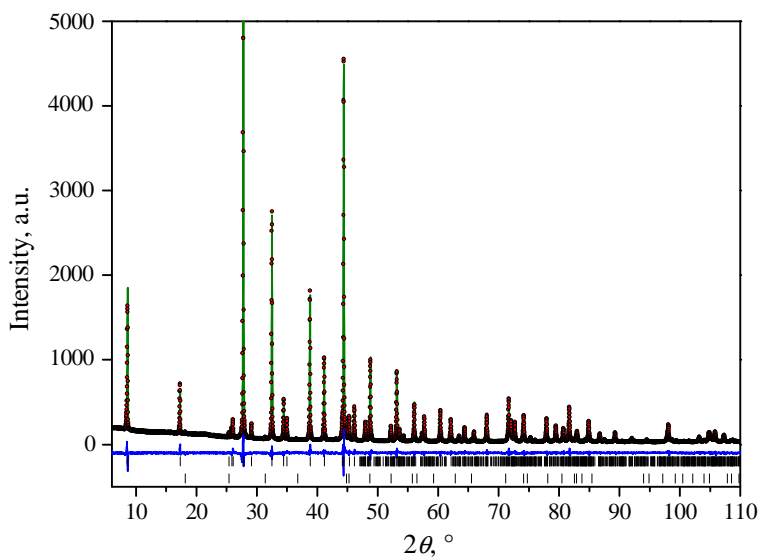

Fig. 2 Experimental, calculated and difference between experimental and calculated X-ray powder diffraction patterns $\left(\mathrm{Cu} K \alpha_{1}\right.$ radiation) for the sample $\mathrm{Ho}_{12.5} \mathrm{Ni}_{12.5} \mathrm{Al}_{50} \mathrm{Ge}_{25}$. Vertical bars indicate the positions of the reflections of $\mathrm{HoNiAl}_{4} \mathrm{Ge}_{2}$ and $\mathrm{Ni}_{2} \mathrm{Al}_{3}$.

The coordination polyhedron of the $R$ atoms has 18 vertices and can be considered as a combination of two octahedra of compositions $\mathrm{Al}_{6}$ and $\mathrm{Ge}_{6}$ and a hexagon of $R$ atoms. The $\mathrm{Ni}$ atoms are situated inside $\mathrm{Al}_{8}$ cubes. The $\mathrm{Al}$ atoms from the site $\mathrm{All}$ are located inside octahedra $\mathrm{Al}_{6}$, having in addition three $\mathrm{Ni}$ atoms and one $\mathrm{Ge}$ atom at contact distances. The $\mathrm{Al}$ atoms from the site $\mathrm{Al} 2$ exhibit trigonal-prismatic coordination. The prisms have the composition $\mathrm{Al}_{3} \mathrm{Ge}_{3}$ and one triangular face is capped by a $\mathrm{Ni}$ atom. The coordination polyhedron of the Ge atoms is built up of three $R$ and four $\mathrm{Al}$ atoms and can be described as a slightly deformed octahedron of composition $R_{3} \mathrm{Al}_{3}$ with one additional $\mathrm{Al}$ atom.

The structure of the compounds $R \mathrm{NiAl}_{4} \mathrm{Ge}_{2}$ belongs to the family of structures with cubic coordination of the smallest atoms (here the $\mathrm{Ni}$ atoms), which corresponds to class \#8 of the classification by P. Kripyakevich [16]. The Ni atoms are located at the centers of cubes formed by $\mathrm{Al}$ atoms. According to the database Pearson's Crystal Data [1], a similar atomic environment of $\mathrm{Ni}$ atoms is observed in six other structure types, defined on quaternary and ternary compounds: $\mathrm{Tb}_{2} \mathrm{NiAl}_{4} \mathrm{Ge}_{2}$ [6], $\mathrm{Ce}_{2} \mathrm{NiAl}_{5.77} \mathrm{Ge}_{2.64}$ [6], $\mathrm{Sm}_{2} \mathrm{Ni}\left(\mathrm{Ni}_{0.27} \mathrm{Si}_{0.73}\right) \mathrm{Al}_{4} \mathrm{Si}_{6} \quad(t P 28, \quad P 4 / n m m) \quad$ [17], $\mathrm{Y}_{3} \mathrm{TaNi}_{6+x} \mathrm{Al}_{26}(c P 49, P m-3 m)$ [18], $\mathrm{Dy}_{4} \mathrm{Ni}_{9} \mathrm{Al}_{24}(a P 39$, $P$-1) [19], and $\mathrm{YbNi}_{3} \mathrm{Al}_{9.23}(h R 81, R 32)$ [20] (Fig. 3).

In the tetragonal $\mathrm{Tb}_{2} \mathrm{NiAl}_{4} \mathrm{Ge}_{2}[6]$ and rhombohedral $\mathrm{SmNiAl}_{4} \mathrm{Ge}_{2}$ [7] structure types the atoms are wellordered; the $\mathrm{Ni}$ atoms occupy only one Wyckoff position. In the tetragonal structure type $\mathrm{Ce}_{2} \mathrm{NiAl}_{5.77} \mathrm{Ge}_{2.64}$ [6], the different elements also occupy distinct sites, but two of the atom sites are partly occupied. 
Table 2 Details of the structural refinements of the compounds $R \mathrm{NiAl}_{4} \mathrm{Ge}_{2}$ (space group $R-3 m, R$ in $3 b 00$ 1/2, $\mathrm{Ni}$ in $3 a 000, \mathrm{Al}, \mathrm{Al} 2$, and $\mathrm{Ge}$ in $6 c 00 \mathrm{z}, Z=3$ ).

\begin{tabular}{|c|c|c|c|c|c|c|}
\hline Compound & $\mathrm{GdNiAl}_{4} \mathrm{Ge}_{2}$ & $\mathrm{TbNiAl}_{4} \mathrm{Ge}_{2}$ & DyNiAl ${ }_{4} \mathrm{Ge}_{2}$ & $\mathrm{HoNiAl}_{4} \mathrm{Ge}_{2}$ & $\mathrm{TmNiAl}_{4} \mathrm{Ge}_{2}$ & $\mathrm{LuNiAl}_{4} \mathrm{Ge}_{2}$ \\
\hline \multirow[t]{2}{*}{ Cell parameters, $\AA$ : $a$} & $4.09456(9)$ & $4.08419(7)$ & $4.08274(7)$ & $4.07878(3)$ & $4.06883(3)$ & $4.06074(3)$ \\
\hline & $30.9672(9)$ & $30.8699(7)$ & $30.7857(7)$ & $30.7444(3)$ & $30.6533(3)$ & $30.5992(3)$ \\
\hline Cell volume $V, \AA^{3}$ & $449.623(12)$ & $445.943(14)$ & $444.410(15)$ & $442.952(6)$ & $439.487(7)$ & $436.970(6)$ \\
\hline Density $D_{\mathrm{X}}, \mathrm{g} \mathrm{cm}^{-3}$ & 5.196 & 5.258 & 5.317 & 5.361 & 5.449 & 5.549 \\
\hline \multirow[t]{3}{*}{ FWHM parameters: $U$} & $0.264(8)$ & $0.163(5)$ & $0.091(5)$ & $0.055(1)$ & $0.069(2)$ & $0.049(1)$ \\
\hline & $-0.072(5)$ & $-0.052(3)$ & $-0.028(3)$ & $-0.020(1)$ & $-0.014(1)$ & $-0.017(1)$ \\
\hline & $0.0165(6)$ & $0.0172(5)$ & $0.0138(5)$ & $0.0139(3)$ & $0.0129(2)$ & $0.0126(2)$ \\
\hline Mixing parameter $\eta$ & $0.779(8)$ & $0.743(7)$ & $0.774(9)$ & $0.621(3)$ & $0.668(4)$ & $0.597(4)$ \\
\hline Asymmetry parameter $C_{\mathrm{M}}$ & $-0.060(4)$ & $-0.079(2)$ & $-0.083(3)$ & $-0.082(2)$ & $-0.078(2)$ & $-0.091(2)$ \\
\hline $\begin{array}{l}\text { Texture parameter } G \text {, direction } \\
{[001]}\end{array}$ & $1.021(3)$ & $1.050(2)$ & $1.054(2)$ & $1.124(1)$ & $1.094(1)$ & $1.103(1)$ \\
\hline Number of reflections & 103 & 100 & 100 & 100 & 100 & 100 \\
\hline Number of refined parameters & 17 & 17 & 17 & 20 & 17 & 17 \\
\hline Atomic coordinates: $z(\mathrm{Al1})$ & $0.3108(2)$ & $0.3111(1)$ & $0.3114(2)$ & $0.3112(1)$ & $0.3110(1)$ & $0.3106(1)$ \\
\hline$z(\mathrm{Al} 2)$ & $0.0773(2)$ & $0.0776(1)$ & $0.0778(2)$ & $0.0780(1)$ & $0.0781(1)$ & $0.0781(1)$ \\
\hline$z(\mathrm{Ge})$ & $0.2239(1)$ & $0.2232(1)$ & $0.2227(1)$ & $0.2225(1)$ & $0.2219(1)$ & $0.2214(1)$ \\
\hline \multirow{4}{*}{$\begin{array}{l}\text { Isotropic } \\
\text { displacement } \\
\text { parameters, } \AA^{2} \text { : }\end{array}$} & $0.45(7)$ & $1.11(5)$ & $0.99(6)$ & $0.88(2)$ & $0.87(2)$ & $1.06(2)$ \\
\hline & $0.56(13)$ & $0.53(8)$ & $1.13(12)$ & $0.27(3)$ & $0.61(4)$ & $0.77(5)$ \\
\hline & $0.60(13)$ & $0.62(8)$ & $1.14(11)$ & $0.44(3)$ & $0.78(4)$ & $0.79(5)$ \\
\hline & $0.77(9)$ & $0.72(5)$ & $1.21(8)$ & $0.57(2)$ & $0.74(2)$ & $0.90(3)$ \\
\hline \multirow[t]{3}{*}{ Reliability factors: } & 0.0622 & 0.0741 & 0.0823 & 0.0321 & 0.0382 & 0.0440 \\
\hline & 0.0344 & 0.0331 & 0.0353 & 0.0529 & 0.0623 & 0.0726 \\
\hline & 0.0434 & 0.0424 & 0.0539 & 0.0725 & 0.0878 & 0.0934 \\
\hline
\end{tabular}

Table 3 Interatomic distances and coordination polyhedra in the six new compounds $R \mathrm{NiAl}_{4} \mathrm{Ge}_{2}$.

\begin{tabular}{|c|c|c|c|c|c|c|c|c|}
\hline \multirow{2}{*}{\multicolumn{2}{|c|}{ Atoms }} & \multicolumn{6}{|c|}{$\delta, \AA$} & \multirow{2}{*}{ Polyhedron } \\
\hline & & $\mathrm{Gd}$ & $\mathrm{Tb}$ & Dy & Ho & $\mathrm{Tm}$ & $\mathrm{Lu}$ & \\
\hline$R$ & $\begin{array}{l}-6 \mathrm{Ge} \\
-6 \mathrm{Al} 2 \\
-6 R\end{array}$ & $\begin{array}{l}2.9546(19) \\
3.640(5) \\
4.09456(9)\end{array}$ & $\begin{array}{l}2.9336(18) \\
3.622(2) \\
4.08419(7)\end{array}$ & $\begin{array}{l}2.9210(18) \\
3.611(5) \\
4.08274(7)\end{array}$ & $\begin{array}{l}2.9141(18) \\
3.602(2) \\
4.07878(3)\end{array}$ & $\begin{array}{l}2.8957(18) \\
3.590(2) \\
4.06883(3)\end{array}$ & $\begin{array}{l}2.8812(18) \\
3.583(2) \\
4.06074(3)\end{array}$ & \\
\hline $\mathrm{Ni}$ & $\begin{array}{l}-2 \mathrm{Al} 2 \\
-6 \mathrm{Al1}\end{array}$ & $\begin{array}{l}2.394(6) \\
2.4648(18)\end{array}$ & $\begin{array}{l}2.396(3) \\
2.4559(9)\end{array}$ & $\begin{array}{l}2.395(6) \\
2.4520(17)\end{array}$ & $\begin{array}{l}2.398(3) \\
2.4512(9)\end{array}$ & $\begin{array}{l}2.394(3) \\
2.4469(9)\end{array}$ & $\begin{array}{l}2.390(3) \\
2.4455(9)\end{array}$ & \\
\hline Al1 & $\begin{array}{l}-3 \mathrm{Ni} \\
-3 \mathrm{Al1} \\
-1 \mathrm{Ge} \\
-3 \mathrm{Al} 2\end{array}$ & $\begin{array}{l}2.4648(18) \\
2.745(5) \\
2.691(7) \\
2.909(5)\end{array}$ & $\begin{array}{l}2.4559(9) \\
2.729(2) \\
2.714(4) \\
2.912(3)\end{array}$ & $\begin{array}{l}2.4520(17) \\
2.717(4) \\
2.731(7) \\
2.918(5)\end{array}$ & $\begin{array}{l}2.4512(9) \\
2.720(2) \\
2.727(4) \\
2.915(3)\end{array}$ & $\begin{array}{l}2.4469(9) \\
2.719(2) \\
2.731(4) \\
2.905(3)\end{array}$ & $\begin{array}{l}2.4455(9) \\
2.726(2) \\
2.729(4) \\
2.893(3)\end{array}$ & \\
\hline $\mathrm{Al} 2$ & $\begin{array}{l}-1 \mathrm{Ni} \\
-3 \mathrm{Ge} \\
-3 \mathrm{All}\end{array}$ & $\begin{array}{l}2.394(6) \\
2.565(3) \\
2.909(5)\end{array}$ & $\begin{array}{l}2.396(3) \\
2.5630(17) \\
2.912(3)\end{array}$ & $\begin{array}{l}2.395(6) \\
2.565(3) \\
2.918(5)\end{array}$ & $\begin{array}{l}2.398(3) \\
2.5621(17) \\
2.915(3)\end{array}$ & $\begin{array}{l}2.394(3) \\
2.5617(17) \\
2.905(3)\end{array}$ & $\begin{array}{l}2.390(3) \\
2.5629(17) \\
2.893(3)\end{array}$ & \\
\hline $\mathrm{Ge}$ & $\begin{array}{l}-3 \mathrm{Al} 2 \\
-1 \mathrm{Al1} \\
-3 R\end{array}$ & $\begin{array}{l}2.565(3) \\
2.691(7) \\
2.9546(19)\end{array}$ & $\begin{array}{l}2.5630(17) \\
2.714(4) \\
2.9336(18)\end{array}$ & $\begin{array}{l}2.565(3) \\
2.731(7) \\
2.9210(18)\end{array}$ & $\begin{array}{l}2.5621(17) \\
2.727(4) \\
2.9141(18)\end{array}$ & $\begin{array}{l}2.5617(17) \\
2.731(4) \\
2.8957(18)\end{array}$ & $\begin{array}{l}2.5629(17) \\
2.729(4) \\
2.8812(18)\end{array}$ & \\
\hline
\end{tabular}




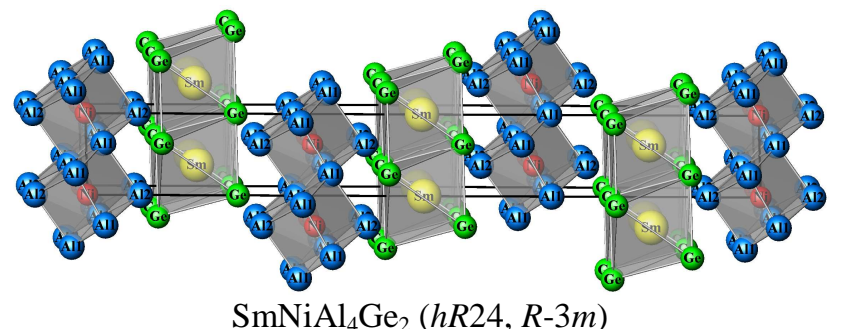

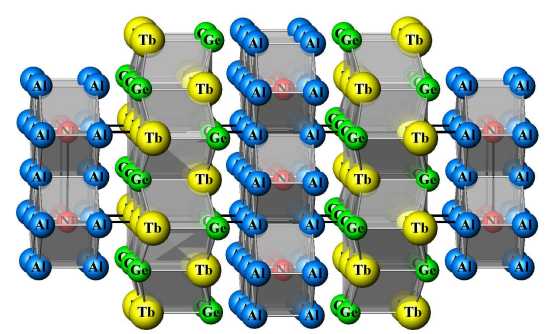

$\mathrm{Tb}_{2} \mathrm{NiAl}_{4} \mathrm{Ge}_{2}(t I 18, I 4 / \mathrm{mmm})$
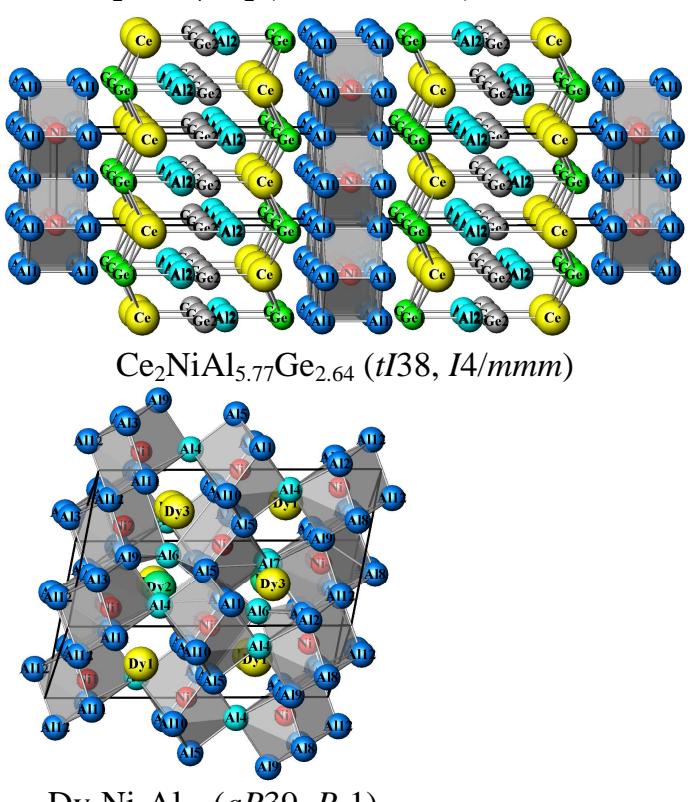

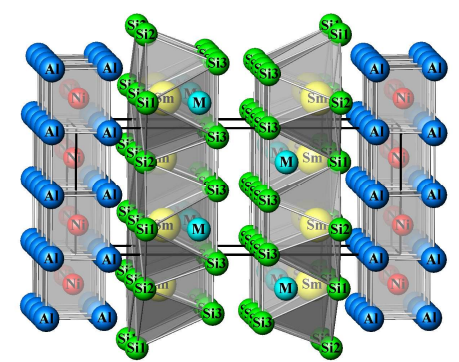

$\mathrm{Sm}_{2} \mathrm{Ni}\left(\mathrm{Ni}_{0.27} \mathrm{Si}_{0.73}\right) \mathrm{Al}_{4} \mathrm{Si}_{6}(t P 28, P 4 /$ nmm $)$

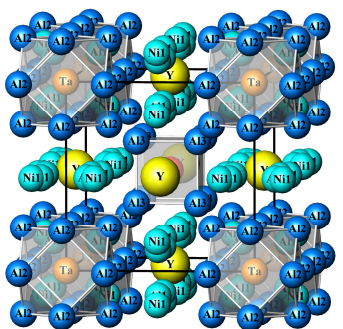

$\mathrm{Y}_{3} \mathrm{TaNi}_{6+x} \mathrm{Al}_{26}(c P 49, P m-3 m)$

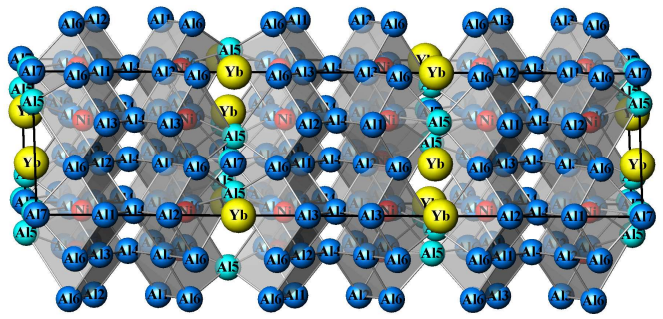

$\mathrm{YbNi}_{3} \mathrm{Al}_{9.23}(h R 81, R 32)$

Fig. 3 The structure type $\mathrm{SmNiAl}_{4} \mathrm{Ge}_{2}$ and related quaternary structure types, emphasizing the arrangement of Ni-centered cubes $\mathrm{Al}_{8}$.

In the tetragonal structure type $\mathrm{Sm}_{2} \mathrm{Ni}\left(\mathrm{Ni}_{0.27} \mathrm{Si}_{0.73}\right) \mathrm{Al}_{4} \mathrm{Si}_{6}$ [17] the Ni atoms are situated on two sites belonging to different Wyckoff positions; the first one is occupied exclusively by $\mathrm{Ni}$ atoms, while the second one is occupied by a statistical mixture of $\mathrm{Ni}$ and $\mathrm{Si}$ atoms. In the cubic structure type $\mathrm{Y}_{3} \mathrm{TaNi}_{6+x} \mathrm{Al}_{26}$ [18] the $\mathrm{Ni}$ atoms are also located in two Wyckoff positions; the first one is only partly occupied by $\mathrm{Ni}$ atoms, whereas the second one is part of a split site occupied by a statistical mixture of $\mathrm{Ni}$ and $\mathrm{Al}$ atoms. The triclinic $\mathrm{Dy}_{4} \mathrm{Ni}_{9} \mathrm{Al}_{24}$ [19] and rhombohedral $\mathrm{YbNi}_{3} \mathrm{Al}_{9.23}$ [20] structure types have an ordered distribution of the chemical elements, but some sites are partly vacant.

In the above mentioned structures the $\mathrm{Al}_{8}$ cubes are connected by common edges and centered by $\mathrm{Ni}$ atoms, forming slabs. This arrangement of cubes in a slab corresponds to the simple $\mathrm{CaF}_{2}$-type structure, where the space is completely filled by $\mathrm{F}_{8}$ cubes, but every second cube is empty [21]. The structure type $\mathrm{Y}_{3} \mathrm{TaNi}_{6+x} \mathrm{Al}_{26}$ represents an exception, since in this structure the cube of $\mathrm{Al}$ atoms, centered by a $\mathrm{Ni}$ atom, is located at the centre of the cell and is isolated from other cubes. The other quaternary structures can be considered as formed by two types of slab, alternating along the crystallographic direction [001]. Similar slabs of $\mathrm{Al}_{8}$ cubes are present in all these structures, but the slabs of cubes are separated by different slabs. In the structure of $\mathrm{SmNiAl}_{4} \mathrm{Ge}_{2}$ the second type of slab can be seen as formed by octahedra of composition $\mathrm{Ge}_{6}$, with every second octahedron centered by a Sm atom. In the structure of $\mathrm{Tb}_{2} \mathrm{NiAl}_{4} \mathrm{Ge}_{2}$ the second slab is built from slightly deformed empty cubes of composition $\mathrm{Tb}_{4} \mathrm{Ge}_{4}$, whereas in $\mathrm{Ce}_{2} \mathrm{NiAl}_{5.77} \mathrm{Ge}_{2.64}$ similar deformed cubes of composition $\mathrm{Ce}_{4} \mathrm{Ge}_{4}$, which form the second slab, are in part centered by $\mathrm{Al}$ or $\mathrm{Ge}$ atoms. 
In the structure of $\mathrm{Sm}_{2} \mathrm{Ni}\left(\mathrm{Ni}_{0.27} \mathrm{Si}_{0.73}\right) \mathrm{Al}_{4} \mathrm{Si}_{6}$ along the crystallographic direction [001] the slabs of $\mathrm{Al}_{8}$ cubes are separated by two layers of square antiprisms of composition $\mathrm{Si}_{8}$ centered by $\mathrm{Sm}$ atoms. Additional $\mathrm{Si}$ or $\mathrm{Ni}$ atoms in statistical disorder are situated in voids (square pyramids) inside the slabs of antiprisms.

In the structures of $\mathrm{Tb}_{2} \mathrm{NiAl}_{4} \mathrm{Ge}_{2}$, $\mathrm{Ce}_{2} \mathrm{NiAl}_{5.77} \mathrm{Ge}_{2.64}$, and $\mathrm{Sm}_{2} \mathrm{Ni}\left(\mathrm{Ni}_{0.27} \mathrm{Si}_{0.73}\right) \mathrm{Al}_{4} \mathrm{Si}_{6}$, every $\mathrm{Ni}$-centered $\mathrm{Al}_{8}$ cube is connected to four others by sharing edges, forming walls with the thickness of the side-length of one cube. In the structure of $\mathrm{SmNiAl}_{4} \mathrm{Ge}_{2}$ the cubes are oriented so that a cube diagonal is perpendicular to the slab. Each cube is connected to six other cubes via common edges, so that corrugated slabs are formed.

The ternary structures of $\mathrm{Dy}_{4} \mathrm{Ni}_{9} \mathrm{Al}_{24}$ and $\mathrm{YbNi}_{3} \mathrm{Al}_{9.23}$ can be described as three-dimensional packings of slightly deformed cubes of composition $\mathrm{Al}_{8}$ centered by $\mathrm{Ni}$ atoms. Dy or $\mathrm{Yb}$ and additional $\mathrm{Al}$ atoms are located in the voids of the framework.

\section{Conclusions}

The structure of the quaternary compounds $R \mathrm{NiAl}_{4} \mathrm{Ge}_{2}$ ( $R=\mathrm{Gd}$, Tb, Dy, Ho, Tm, Lu) belongs to the $\mathrm{SmNiAl}_{4} \mathrm{Ge}_{2}$ type. The structure of the $\mathrm{SmNiAl}_{4} \mathrm{Ge}_{2}$ type may be described as formed by slabs of Ni-centered cubes $\mathrm{Al}_{8}$, alternating with $\mathrm{Sm}$-centered octahedra $\mathrm{Ge}_{6}$. Ni-centered cubes $\mathrm{Al}_{8}$ seem to be a particularly stable structural element since similar cubes are observed in the structures of other quaternary and ternary aluminides with rare-earth metal and nickel, as shown for the types $\mathrm{Tb}_{2} \mathrm{NiAl}_{4} \mathrm{Ge}_{2}$, $\mathrm{Ce}_{2} \mathrm{NiAl}_{5.77} \mathrm{Ge}_{2.64}, \quad \mathrm{Sm}_{2} \mathrm{Ni}\left(\mathrm{Ni}_{0.27} \mathrm{Si}_{0.73}\right) \mathrm{Al}_{4} \mathrm{Si}_{6}$, $\mathrm{Y}_{3} \mathrm{TaNi}_{6+x} \mathrm{Al}_{26}, \quad \mathrm{Dy}_{4} \mathrm{Ni}_{9} \mathrm{Al}_{24}$, and $\mathrm{YbNi}_{3} \mathrm{Al}_{9.23}$. The quaternary structures, with the exception of $\mathrm{Y}_{3} \mathrm{TaNi}_{6+x} \mathrm{Al}_{26}$, can be considered as formed by two types of slab alternating along the crystallographic direction [001], one of them being built up of Ni-centered cubes $\mathrm{Al}_{8}$. The ternary structures can be described as a 3D-stacking of slightly deformed Ni-centered cubes $\mathrm{Al}_{8}$.

\section{Acknowledgements}

This work was supported by the Ministry of Education and Science of Ukraine (grant No. 0118U003609).

\section{References}

[1] P. Villars, K. Cenzual (Eds.), Pearson's Crystal Data - Crystal Structure Database for Inorganic Compounds, ASM International, Materials Park, OH, USA, Release 2016/17.

[2] N. Semuso, Yu. Lutsyshyn, S. Pukas, Ya. Tokaychuk, R. Gladyshevskii, Visn. Lviv. Univ., Ser. Khim. 57 (2016) 89-96.
[3] N. Semuso, S. Pukas, Ya. Tokaychuk, R. Gladyshevskii, Coll. Abstr. 19 Int. Conf. Solid Compd. Transition Elem., Genoa, 2014, p. 148.

[4] P. Demchenko, J. Konczyk, G. Demchenko, R. Gladyshevskii, V. Pavlyuk, Acta Crystallogr. C 62 (2006) i29-i31.

[5] J.T. Zhao, E. Parthé, Acta Crystallogr. C 46 (1990) 2273-2276.

[6] B. Sieve, P.N. Trikalitis, M.G Kanatzidis, Z. Anorg. Allg. Chem. 628 (2002) 1568-1574.

[7] B. Sieve, X. Chen, J. Cowen, P. Larson, S.D. Mahanti, M.G. Kanatzidis, Chem. Mater. 11 (1999) 2451-2455.

[8] N. Muts, L. Akselrud, R. Gladyshevskii, Coll. Abstr. IX Int. Conf. Crystal Chem. Intermet. Compd., Lviv, 2005, p. 151.

[9] G. Demchenko, J. Konczyk, P. Demchenko, O. Bodak, B. Marciniak, Acta Crystallogr. E 61 (2005) i273-i274.

[10] G. Demchenko, J. Konczyk, P. Demchenko, R. Gladyshevskii, W. Majnzer, L. Muratova, Chem. Met. Alloys 1 (2008) 254-260.

[11] X. Wu, M.G. Kanatzidis, J. Solid State Chem. 178 (2005) 3233-3242.

[12] R.A. Young (Ed.), The Rietveld Method, Oxford University Press, Oxford, United Kingdom, 1995, 298 p.

[13] R.A. Young, A. Sakthivel, T.S. Moss, C.O. Paiva-Santos, J. Appl. Crystallogr. 28 (1995) 366-367.

[14] E. Dowty, ATOMS. A Computer Program for Displaying Atomic Structures, Kingsport, TN, USA, 1999.

[15] E. Teatum, K. Gschneidner, J. Waber, Report No. LA-2345, US Department of Commerce, Washington, D.C., USA, 1960.

[16] P.I. Kripyakevich, Structure Types of Intermetallic Compounds, Nauka, Moscow, 1977, 288 p. (in Russian).

[17] X.Z. Chen, S. Sportouch, B. Sieve, P.W. Brazis, C.R. Kannewurf, J.A. Cowen, R. Patschke, M.G. Kanatzidis, Chem. Mater. 10 (1998) 3202-3211.

[18] R.E. Gladyshevskii, K. Cenzual, J. Alloys Compd. 240 (1996) 266-271.

[19] I. Kurylyshyn, Yu. Lutsyshyn, V. Hlukhyy, T. Fässler, R. Gladyshevskii, Coll. Abstr. XI Int. Conf. Crystal Chem. Intermet. Compd., Lviv, 2010, p. 115.

[20] P.H. Tobash, Y. Jiang, F. Ronning, C.H. Booth, J.D. Thompson, B.L. Scott, E.D. Bauer, J. Phys.: Condens. Matter 23 (2011) 086002.

[21] E. Parthé, L. Gelato, B. Chabot, M. Penzo, K. Cenzual, R. Gladyshevskii, TYPIX. Standardized Data and Crystal Chemical Characterization of Inorganic Structure Types, Springer-Verlag, Berlin, Germany, 1993/1994, Vols. 1-4, 1596 p. 